\title{
Advancement and applications of peptide phage display technology in biomedical science
}

\author{
Chien-Hsun Wu, I-Ju Liu, Ruei-Min Lu and Han-Chung Wu
}

\begin{abstract}
Combinatorial phage library is a powerful research tool for high-throughput screening of protein interactions. Of all available molecular display techniques, phage display has proven to be the most popular approach. Screening phage-displayed random peptide libraries is an effective means of identifying peptides that can bind target molecules and regulate their function. Phage-displayed peptide libraries can be used for (i) B-cell and T-cell epitope mapping, (ii) selection of bioactive peptides bound to receptors or proteins, disease-specific antigen mimics, peptides bound to non-protein targets, cell-specific peptides, or organ-specific peptides, and (iii) development of peptide-mediated drug delivery systems and other applications. Targeting peptides identified using phage display technology may be useful for basic research and translational medicine. In this review article, we summarize the latest technological advancements in the application of phage-displayed peptide libraries to applied biomedical sciences.
\end{abstract}

Keywords: Phage display, Peptides, Epitope mapping, Antigen mimics, Drug delivery

\section{Background}

Phage display is a selection technique in which a peptide or protein is fused with a bacteriophage coat protein and displayed on the surface of a virion. This technology was first described by George P. Smith in 1985, when he demonstrated the display of peptides on filamentous phage by fusing the peptide of interest to gene III of filamentous phage [1]. Phage-displayed random peptide libraries enable functional access to the peptides and provide a physical link between phenotype (the displayed peptide) and genotype (the encoding DNA); these libraries lend themselves to a screening process in which binding clones are separated from nonbinding clones by affinity purification.

Peptides binding to individual targets can be identified by affinity selection (called biopanning). For biopanning, a display library is incubated with an immobilized target, followed by extensive washing to remove nonreacting phages. Binders are usually eluted using acid or high salt and are enriched by amplification in the appropriate host

\footnotetext{
* Correspondence: hcw0928@gate.sinica.edu.tw

Institute of Cellular and Organismic Biology, Academia Sinica, 128 Academia Road, Section 2, Nankang, Taipei 11529, Taiwan
}

cells. Three to five rounds of biopanning are usually performed in order to obtain targets that bind with high affinity (Fig. 1). The primary structure of the peptide can then be determined by sequencing the DNA of individual clones. Using this approach, it is easy to identify peptides that bind specifically to target molecules.

Phage-displayed peptide library can be used in B-cell and T-cell epitope mapping, selection of bioactive peptides bound to receptors or proteins, selection of diseasespecific antigen mimics, selection of peptides bound to non-protein targets, selection of cell-specific peptides, selection of organ-specific peptides, and development of peptide-mediated drug delivery systems and other applications. Targeting peptides identified using phage-displayed peptide libraries have potential use in basic research and translational medicine. In this review paper, we discuss in detail each of the applications of the phage-displayed technology platform in the biomedical sciences.

\section{B-cell and T-cell epitope mapping}

Upon encountering antigen, host humoral immunity activates and triggers production of antibodies directed against foreign protein epitopes. Knowledge of these 


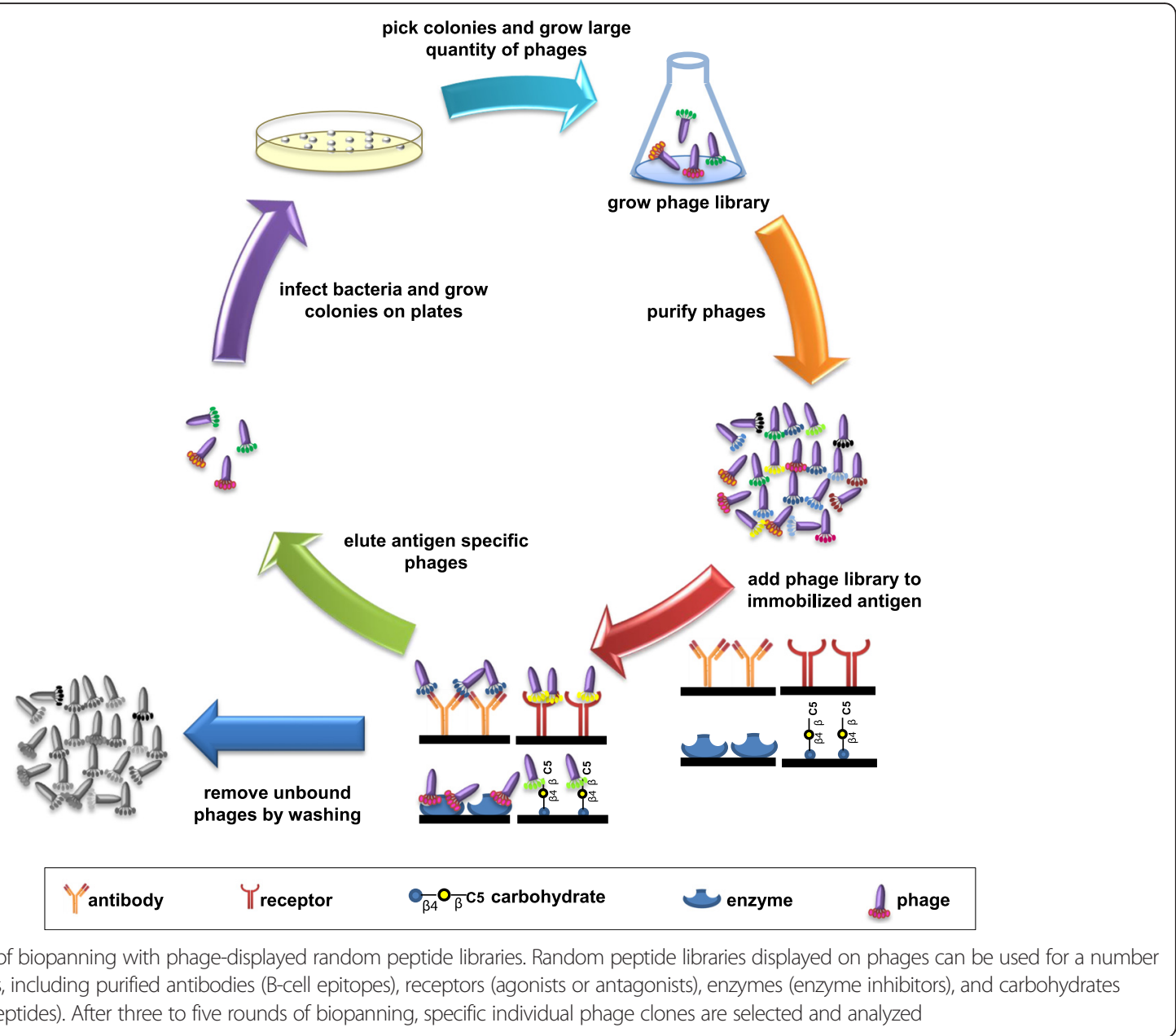

protein epitopes is pivotal in understanding the pathogenesis of pathogen infections and in developing diagnostic reagents, therapeutic antibodies, and effective vaccines. An epitope (known as an antigenic determinant) is recognized by components of the immune system, including antibodies, B cells, and T cells. The epitopes of antigens, which are dependent on their structural properties, can be either linear or conformational [2]. Linear epitopes have some continuous amino acid sequences of antigens, which correspond with their primary structure. In contrast, conformational epitopes contain discontinuous amino acid sequences of antigens, which are based on their protein tertiary structure. There are several experimental methods with which to identify B-cell epitopes, such as Pepscan [3], co-crystallization [4], nuclear magnetic resonance (NMR) [5], computational docking [6], and site-directed mutagenesis [7]. The phage display method provides an economical and rapid approach with which to map B-cell epitopes [8-10]. Previous studies have used various phagedisplayed random peptide libraries to identify B-cell epitopes [11-15] or neutralizing epitopes [11, 14, 16] from monoclonal antibodies (mAbs). In addition to mAbs, polyclonal antibodies (e.g. special sera from patients or immunized mice) can also be captured on solid disks or magnetic beads, and then reacted with a comprehensive library of random peptides. Peptides have been selected by biopanning with antibodies from complex sera of patients with various diseases, including severe acute respiratory syndrome (SARS) [17] and infection with human papillomavirus (HPV) [18] and avian influenza viruses (AIV) [19]. Based on information on B-cell epitopes from polyclonal antibodies, certain peptide-based antigens are useful for serological diagnosis, and some are suitable for development of vaccines $[17,20,21]$. The selected disease-specific epitopes may prove to be invaluable for the identification of the etiological agent [17] (Fig. 2).

\section{Selection of disease-specific antigen mimics}

The considerable potential of phage display peptide libraries lies in their capacity to identify some peptide molecules that mimic epitopes (named mimotopes). Mimotopes have fewer similarities to primary amino acids of antigens and always show discontinuous sequences, but they can elicit an identical or highly 


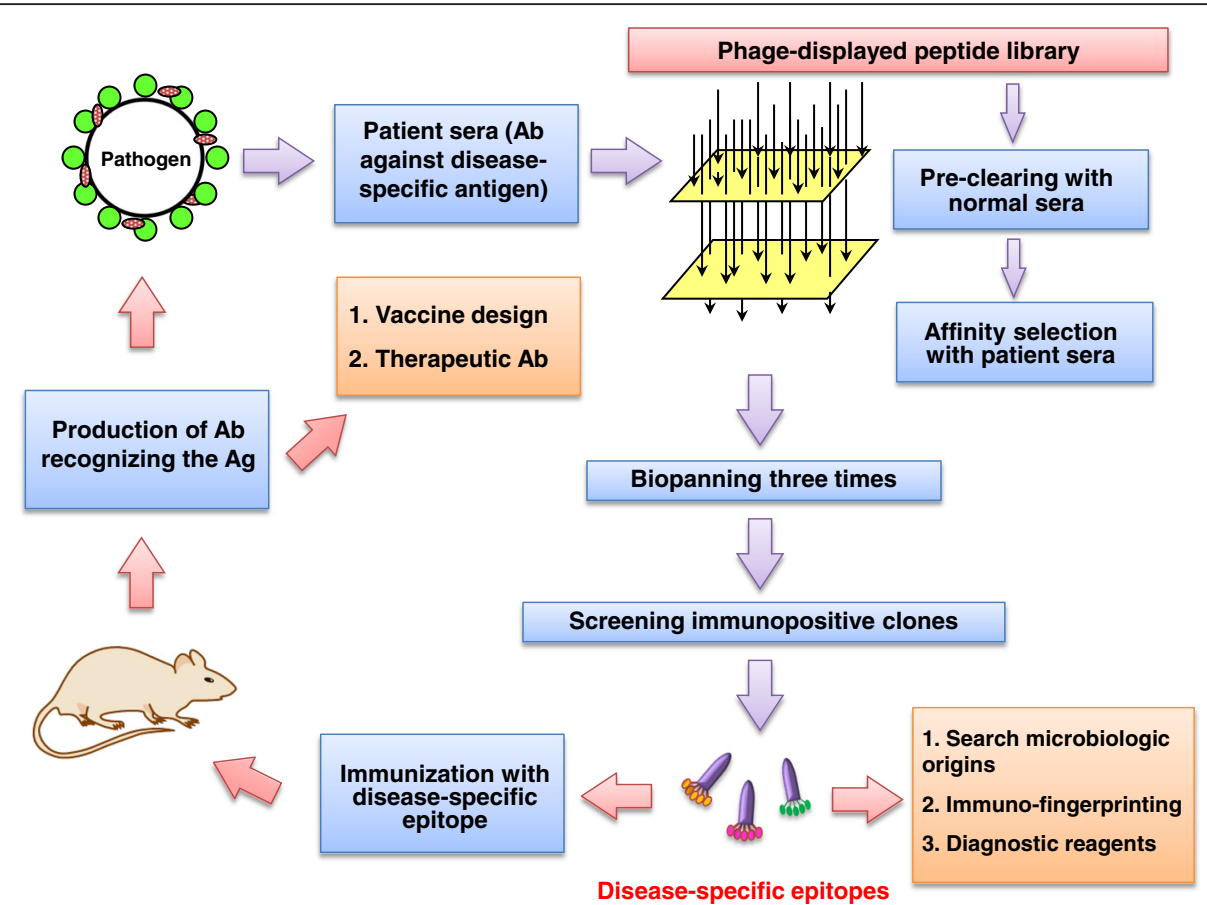

Fig. 2 Biopanning selection of phage-displayed peptide libraries using serum samples. The phage-displayed peptide library was precleared using normal human sera and selected with serum antibodies (Abs) from patients with candidate diseases. After three rounds of biopanning, immunopositive phage clones were screened by ELISA. Disease-specific epitopes were further identified and characterized by synthetic peptide binding and competitive-inhibition assays. Phage-displayed disease-specific epitopes can be used to determine microbiological origins, study immunotyping, or provide information for the development of diagnostic reagents and vaccines

similar antibody response to that of the native epitope. The development of diagnostic or preventive reagents requires screening phage-displayed peptide libraries for disease-specific epitopes/mimotopes in serum or cerebrospinal fluid samples obtained from patients with viral infections [22, 23], rheumatoid arthritis [24], multiple sclerosis [25], autoimmune thrombocytopenic purpura [26, 27], and neurocysticercosis [28]. Peptides have been selected by biopanning serum samples from patients infected with HPV [18], SARS [17], and AIV [19]. Mimotope-based detection is suitable for broad spectrum antibodies against avian H5N1 influenza virus [29], and has been shown to improve serological detection of SARS [17] and rheumatoid arthritis [30]. Another example is recently identified cholera toxin-binding peptides. Cholera toxin, which is secreted by Vibrio cholerae, can enter host cells by binding to GM1, a monosialoganglioside, and would result in acute diarrhea. Biopanning with cholera toxin B (CTB) subunit to select CTB-binding peptides that structurally mimic GM1 could serve as novel agents to block CTB binding on epithelial cells and prevent the ensuing physiological effects of cholera toxin [31].

Mimotopes can also be used to characterize unknown initiating events and provide clues toward disease pathogenesis. Biopanning with antibodies from systemic sclerosis patients was used to screen an immunopositive peptide that had a high degree of similarity to autoantigens, including heterogenous ribonucleoproteins (hnRNP), cytochrome c, fibrillarin, and late protein UL94 of human cytomegalovirus (CMV) [32]. Immunopositive peptide-based affinity purified antibodies from sera of systemic sclerosis patients reacted with a surface component of endothelial cells and induced apoptosis. A dengue anti-NS1 antibody B-cell epitope is cross-reactive to astrocyte elevated gene-1 (AEG-1), a human protein on human endothelial cells that may cause some dengue patients to suffer from hemorrhagic fever (DHF) or dengue shock syndrome (DSS) [33]. Recently, an antigen peptide mimicking alpha-2-Heremans-Schmid glycoprotein, also known as fetuin-A, was identified from serum antibodies of prostate cancer patients [34]. Using this antigen mimic peptide, the authors demonstrated increased serum antibody reactivity to fetuinA during disease progression in the index patient, and strong serum reactivity in a large cohort of metastatic prostate cancer patients [34]. As mentioned above, study of the disease-specific antigen mimics by phage display helps us to understand the etiology of diseases (Fig. 2). 


\section{Selection of bioactive peptides bound to receptors or proteins For receptors}

Membrane receptors are pivotal for cell-cell biochemical and electrical signaling in essential physiological functions. Therefore, the pharmaceutical industries tend to focus on developing drugs targeting membrane receptors $[35,36]$. Novel receptor ligands discovered using phagedisplayed random peptide libraries [37-40] may be either agonists or antagonists (Fig. 1). Two typical examples of agonist peptides selected by phage display are peptides targeting erythropoietin receptor (EpoR) [37] and thrombopoietin receptor (TpoR) [38]. After treatment with Epo mimetic peptide, conformational changes in the extracellular domain of EpoR trigger intracellular signal transduction [37]. This discovery may form the basis for the design of small molecule mimetics of Epo. On the other hand, the selected small peptides targeting TpoR can compete for the binding of the natural ligand, thrombopoietin, and stimulate the proliferation of a TPO-responsive cell line [38]. Antagonists of membrane receptors from phage display have also been reported [41-43]. For example, vascular endothelial growth factor (VEGF) plays an important role in angiogenesis through binding to the kinase domain receptor (KDR/FLK1 or VEGFR2). Peptides as antagonists that block VEGFmediated angiogenesis have been obtained by phage display $[43,44]$. Human CXC ligand 8 (hCXCL8) is a type of chemoattractant that binds to hCXCR1 and hCXCR2, which are involved in inflammation. Inhibition of hCXCL8 binding to hCXCR1 and hCXCR2 by antagonistic peptides has been investigated, and used to develop new therapeutics for treatment of inflammatory diseases [45].

Phage display is also used to isolate receptor-independent peptide modulators, such as $G$ protein-coupled receptors. Some selected peptides from $G$ proteins can interact with the Goi subunit, leading to an elevated sensitivity of guanine nucleotides to bind to A1 adenosine receptors [46] and to $G \beta \gamma$ subunit in order to enhance the dissociation of $G$ protein heterotrimers in vitro, and activate $G$ protein signaling in intact cells [47].

\section{For enzyme inhibitors}

The pathogenesis of some diseases occurs through the expression of abnormal enzymes, which can serve as potential targets for developing inhibitors as new drugs to block the activities of these enzymes. Phage display has been used to identify the peptide substrate inhibitors that modulate enzyme activities [48, 49] (Fig. 1). Because filamentous phages are resistant to a wide range of proteases, they have been used to identify substrates and generate protease inhibitors [50]. Bahudhanapati et al. identified selective inhibitors of collagenase-1 (metalloproteinase 1, MMP-1) by screening variants of tissue inhibitor of metalloproteinases-2 (TIMP-2) using phage display. TIMP-2 is a broad range inhibitor of matrix metalloproteinases (MMPs) [51]. In addition to protease inhibitors, peptide-based inhibitors against various enzymes, such as human HMG-CoA reductase [52], ubiquitin ligases [53], and tyrosinase [54], have all been identified by phagedisplayed random peptide libraries.

\section{Protein-protein interactions}

In cells, protein-protein interactions regulate the mechanisms of several important normal physiological functions. Phage display is a potent and versatile method for studying protein-protein interaction [55-58]. It can be applied to a wide range of protein interaction partners and used in a number of applications, especially in mapping intracellular interactions of the distinct protein domain. Good examples of protein interaction partners include Src homology (SH) 3 domains, which are highly conserved protein interaction modules comprised of 50 to 70 amino acids. SH3 domains are also found in a variety of functionally unrelated proteins. Kärkkäinen et al. generated a library in which all human SH3 domains are expressed on the surface of M13 bacteriophage, thereby enabling analysis of human $\mathrm{SH} 3$ domain binding to target proteins of interest, including human immunodeficiency virus-1 Nef, p21-activated kinase (PAK)2, and ADAM15 [59]. Voss et al. also established similar libraries to define the $\mathrm{SH} 3$ domain that reacts with the intracellular region of Fas ligand. In addition to the known SH3 domains, the authors also identified a number of additional SH3 domains that may also be associated with FasL [60]. CDBP2 is a cellular adapter protein that contains a GYF domain in its C-terminal fragment. Kofler et al. identified a new conserved motif, PPG (W/F/Y/M/L), in the GYF domain of CDBP2, using phage display. Alignment of these consensus motifs to protein databases, in combination with yeast display or NMR methods, has allowed scientists to rapidly identify novel interaction partners of GYF domain $[61,62]$.

\section{Selection of peptides bound to non-protein targets}

Many different types of bacteria trigger protective immune responses through cell surface non-protein antigens, such as polysaccharides. Many tumor antigens are carbohydrates. Epitopes mimicking low immunogenic polysaccharides or carbohydrate antigens can be screened and identified by phage-displayed random peptide libraries [63, 64] (Fig. 1). These isolated peptide mimotopes coupled with carrier proteins can be used as potential vaccine candidates to stimulate stronger antibody responses $[65,66]$.

The phage display technique has also allowed us to identify novel peptides against RNA of interest by screening random peptide libraries $[67,68]$. Selective 
peptides targeting helix 31 of bacterial 16S RNA can be used to inhibit cell-free translation [67]. Bose et al. used phage display to find a selective peptide binding to pre-miR-21, which blocks Dicer processing and decreases miR-21 expression [69].

A few studies have successfully employed peptide phage display to select binders of small molecules, such as fluorophores [70], microcystin-LR [71], and paclitaxel (Taxol) [72]. Recently, Liu et al. performed phage display to screen peptide ligands recognizing an insecticide, imidacloprid, for environmental monitoring in water and soil [73]. The biopanning strategy of phage display can be used to select specific peptides against nanomaterials. These phage-displayed nanomaterial binding peptides are broadly useful in the field of nanotechnology [74]. Whaley et al. showed the power of using combinatorial phagedisplay libraries to select highly specific peptides that bind to a range of crystalline semiconductor structures, such as GaAs, depending on the nanocrystal orientation [75]. The application of specific peptides has been extended to recognize other substrates of inorganic nanocrystals, including $\mathrm{ZnS}, \mathrm{CdS}, \mathrm{TiO}_{2}$, and $\mathrm{SiO}_{2}$, as well as magnetic materials such as $\mathrm{Fe}_{2} \mathrm{O}_{3}$ and $\mathrm{Fe}_{3} \mathrm{O}_{4}$ [76-79]. Peptides derived from phagedisplayed libraries can be specifically bound to a conducting polymer for use as a biomaterial to functionalize the surface of conductive polymers, thereby enabling various electronic and biomedical applications [80]. Moreover, the $\mathrm{Au}-, \mathrm{Ag}_{-}, \mathrm{Ti}-, \mathrm{Pt}-$, and Pdbinding peptides were all acquired using the combinatorial phage display peptide library [81-84]. Such metal and semiconductor-targeting peptides have been genetically engineered for use in nano- and biotechnology, particularly in the molecular biomimetics field [84].

\section{Selection of cell-specific peptides}

Peptide phage display through whole-cell panning offers a high-throughput approach for identifying peptides that bind specifically to a single cell type. Johnston and coworkers were the first to describe the use of peptidedisplayed phage to identify peptide binding to several different cell types [85]. The most common screening method is a process called "biopanning", shown in Fig. 3, in which the binding affinities of the targeted phage clones are enriched. It can be performed in vitro against various types of cells, including cultured cell lines, primary cells isolated from animal models or human patients, or processed cells (fixed cells, activated cells etc.). Within the past ten years, several studies have focused on the in vitro biopanning of phage displayed peptide libraries using various cancer cell types [86-90] to identify cell-specific ligands [91].

Depending on the applications of the ligand, selection can be performed with adherent or fixed cells. The experimental approach can be modified to isolate phages, which bind to the cell surface or peptides, thereby triggering the cellular uptake of the peptides. Peptidedisplayed phage libraries are incubated with the cells for a defined period of time. The cells are subsequently washed to remove non-specific and weakly bound phage. In order to reduce the cross-reactivity of the peptide or the phage, blocking agents such as BSA are occasionally used. Removing unbound phage is required to obtain phage clones with strong binding to the desired target, and remove non-specific binding from the background. In general, the washing processes are relatively gentle; however, more stringent washes may increase the affinity of selected phage clones. In some cases, negative selection is performed to avoid the aforementioned problem. In general negative selection is not essential.

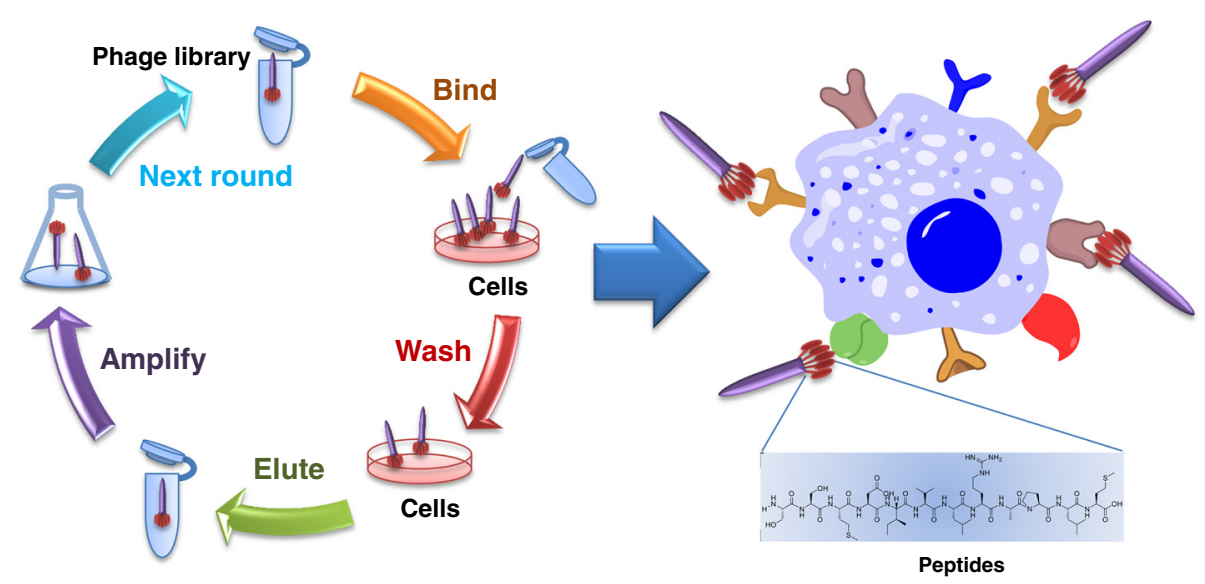

Fig. 3 The working principle for screening of cell-specific peptides from a phage display library. A phage display library was incubated with the cells. Unbound phage was removed using washing buffer, and cells bound to phage were eluded and amplified with E. coli in broth. Enriched phages were used in the next round of panning. After three to five rounds of selection panning, the positively selected phages were collected and sequenced 
Phage bound to the target is recovered using several elution strategies, including the use of acidic buffers, Dithiothreitol, and high ionic strength, which tend to decrease the interaction between the peptide and the target. Most commonly, acidic buffer is sufficient for the elution of target bound phage. However, in the case of strong peptide-target interactions, these elution procedures may only partially break peptide-target interactions, thereby resulting in loss of the high-affinity phage clones. To circumvent this problem, Strukelj and coworkers used a modified method, in which ultrasound was applied during acidic buffer elution to release target-bound phage and enable the selection of highaffinity phage clones [92]. In cases where ligands of a particular target are known and available, competitive elution is the preferred method of isolating the target molecule. This method can specifically elute desired target-bound phage clones while avoiding elution of background-bound phage. Alternatively phage can also be eluted competitively but nonspecifically by using the free target molecule, such as an eluant, or by adding bacterial host directly to the target-bound phage.

Using whole cells instead of purified proteins as target for in vitro biopanning has several advantages. The cellular receptors expressed on live cells can retain their native states (correct protein folding, quaternary structure, expression level, and association with neighboring proteins), and their biological functions and activities. Biopanning with modified protocols can be used for the isolation of peptides that mediate specific cellular functions. For example, selection can be aimed at isolating surface-bound or internalized peptides. Direction elution of phage enables isolation of surface-bound phage. If surface-bound phages are removed by low-pH washes or through treatment with a protease, phage with internalizing characteristics can be isolated. In addition, the use of whole cells for biopanning enables the identification of cell surface molecules with unknown biological functions. This can be used to characterize cell surface profiles and provide information on molecular changes (such as expression level and protein localization) between normal and disease cells.

Although numerous cell-binding peptides have been successfully isolated using in vitro panning against cultured cells, several challenges still remain [91]. In particular, systematic experimental approaches for target identification are lacking [93]. This is a key problem because accurate identification of peptide-targeted molecules is important for basic and clinical research. Conventional receptor identification focuses on membrane protein extraction and affinity purification, followed by mass spectrometric identification of the purified protein. However, the problems associated with this approach arise from the difficulty in maintaining the native interaction between targeting peptide and isolated whole membrane receptor [94]. Furthermore, the binding affinities of targeting peptides are, in general, too low to enable purification by affinity-based methods. Wu and co-workers aimed to overcome the problems outlined above by using biotinylated peptides to directly bind intact cells, and subsequent fixation of ligandreceptor complexes by cross-linking with 3,3'-dithiobis[sulfosuccinimidyl propionate] (DTSSP). After affinity trapping and LC-MS/MS analysis, the unknown target protein on the plasma membrane of the cells could be identified [89]. It is important to note that advances in peptide identification and subsequent receptor identification can lead to the discovery of important cellular targets that were previously unknown. This not only improves our understanding of the molecules expressed in the pathological state, but may also provide useful information on molecules that are not expressed under normal physiological conditions.

\section{Selection of organ-specific peptides}

Organ-specific peptides can be isolated from phage display peptide libraries by performing the selection in a living animal. In vivo phage display technology was first described by Ruoslahti and co-workers in 1996 [95]. They aimed to discover brain vasculature targeting peptides using phage-displayed peptide libraries. Typically, a random peptide phage library is introduced by intravenous injection into the circulation of animal. After a brief circulation time, the animals are sacrificed, and the unbound phage clones are washed off through perfusion of the left ventricle with saline. Based on the half-life of the phage in previous studies, the circulation time of a peptide-displayed phage is generally estimated to be in the 5 to $15 \mathrm{~min}$ time range $[86,96,97]$. There is evidence that the displayed exogenous peptide or protein can exhibit circulation half-lives as short as $1.5 \mathrm{~min}$ to as long as $4.5 \mathrm{~h}$ [98, 99]. Molenaar and co-workers reported that degradation of phage occurs as rapidly as $30 \mathrm{~min}$ after injection [98]. A circulation time of over $30 \mathrm{~min}$ may be caused by lysosomal degradation of phage after uptake by the target tissue.

After removing the unbound phage in circulation, the desired organs are collected and homogenized. The organ-associated phage is recovered from the homogenized tissue. A fraction of the organ lysates are used to infect bacteria for phage amplification and for subsequent rounds of selection in another animal. Another fraction is used for phage titering to measure the amount of recovered phage. After 3-5 rounds of in vivo biopanning, the phage titer recovered from the target tissue should increase [88, 97, 100]. Several peptide motifs are typically identified for a given organ (Fig. 4). 
After biopanning, the specificity of the isolated peptide needs to be further confirmed. In general, wild type phage without insert or phage with scrambled peptide is used as a negative control. The ability of the isolated peptide to home to the target organ can be confirmed either by comparative analysis using a scrambled peptide, or by competitive studies using a combination of synthetic peptide and selected phage clone with identical peptide sequence. Other approaches, such as immunostaining of homing phage, or fluorescent or radioactive labeling of either phage or synthetic peptide, can be used to directly determine the organ tissue distribution.

This approach has been applied to a number of different organs, including brain, kidney, lungs, liver, uterus, muscle, pancreas, thymus, and mammary gland [101]. Various types of tumor and malignant tissue vasculature have been targeted using phage-displayed random peptide libraries [97, 101-105]. In addition to tumor blood vessels, many tumors induce the growth of new lymphatic vessels and change characteristics during tumor development. Several researchers have used the in vivo phage display technology to map tumor-specific differences in the lymphatic vasculature, and have identified peptides that specifically home to tumor lymphatics [106].

Using in vivo phage display technology to identify specific homing peptides is not without pitfalls. Peptides isolated from animal models using this method may not translate to human because of differences in the vasculature and peptide binding between species. Such limitations can be overcome by performing biopanning in humans. The phage library can be injected into terminal human patients and retrieved from human tissues to identify organ specific peptides [107]. Another study reported the use of phage-display libraries in cancer patients to identify tumor-targeting ligands [108]. In vivo phage display has been shown to be an effective and powerful technique for the isolation of peptides that specifically bind to an organ with high affinity and specificity. However, optimization of these peptides is needed to enhance the clinical applicability of in vivo phage display research.

\section{Development of peptide-mediated drug delivery systems}

The delivery of anti-cancer drugs to solid tumors is limited by physical transport barriers within tumors, and such restrictions directly contribute to decreased therapeutic index and the emergence of drug resistance. Drug delivery systems designed to precise spatiotemporal control have demonstrated potential to enhance drug delivery in animal models. Many nanoparticle delivery systems for anticancer drugs have entered the clinic, where they have been shown to exert anticancer effects by improving the pharmacokinetic and pharmacodynamic properties of their associated drugs [109]. Liposomes are the most advanced form of particulate drug carriers. Liposomal systems, like RES-avoiding and longcirculating systems, can confer stable formulation, improved pharmacokinetics, and "passive" targeting of tumor tissue. The newest generation of drug carriers utilizes multicapable nanotechnology-oriented strategies aimed at greater specificity and efficiency. They feature direct molecular targeting of cancer cells via ligandmediated interactions. Molecular targeted drug delivery can be achieved using targeting liposomes created by linking liposomal drugs to specific ligands. The development of targeting liposomes has been made possible by advances in liposomal systems. These two technologies
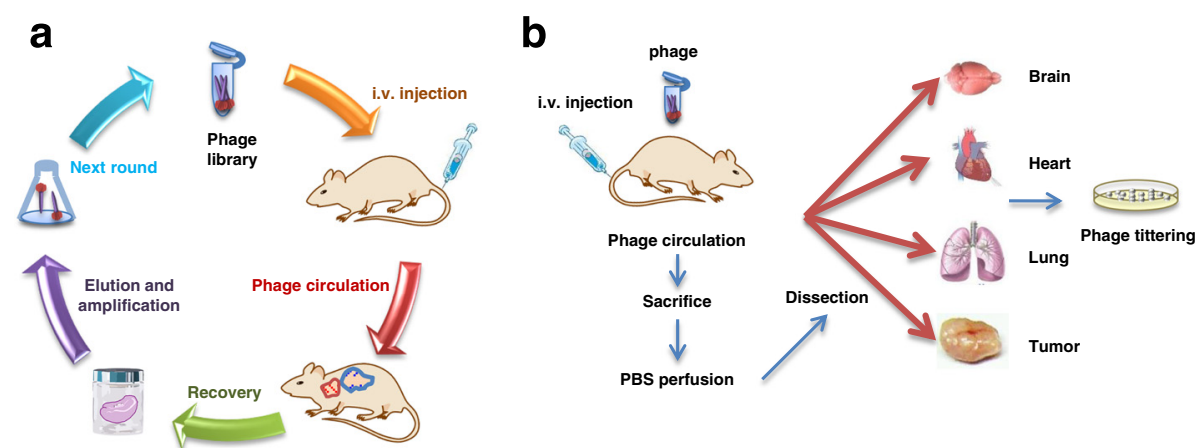

Fig. 4 Use of phage display libraries to identify peptides that bind to a specific organ. a The in vivo process is based on panning the library of peptides against the target organs. The phage peptide library is injected into the mouse's tail vein to allow it to circulate throughout the body. After a few minutes in circulation, phage molecules that bind to organs and tissues of interest are isolated. The isolated phage molecules are amplified and subjected to further rounds of selection to enrich organ-specific phage. Finally, DNA from the phage is sequenced to identify the encoded peptide, and the peptide can be used for the development of organ-specific therapeutics and diagnostics. $\mathbf{b}$ The specificity of selected phage clones can be further confirmed using the phage homing assay. Mice are injected with the selected phage clones through the tail vein. Phage clones are allowed to circulate, and the nonspecific binders are washed out. The organs are subsequently recovered, and the titers of phage in various organs are determined 
can in principle be fully integrated, thus combining the specificity of ligands with the drug delivery capabilities of liposomes (Fig. 5).

Peptide-mediated liposomes include three main components: an anticancer drug, a liposome carrier, and targeting ligands (Fig. 5). Remote loading methods, such as the ammonium sulfate method [110] and the $\mathrm{pH}$ gradient method [111], can encapsulate weak bases, such as doxorubicin or vinorelbine, into the liposomes with more than $95 \%$ efficiency [89]. Schedule-dependent drugs, such as vinca alkaloids and topotecan, are reasonable candidates for liposomal delivery because of their effectiveness at enhancing the exposure time of cancer cells to therapeutic drug levels. The use of peptidemediated liposomes also avoids exposing normal tissue to cytotoxic drugs, and prevents adverse side effects. High tumor interstitial fluid pressure (IFP) is a barrier for efficient drug delivery [112, 113]. Increased IFP contributes to decreased transcapillary transport in tumors, which reduces uptake of drugs. This approach sidesteps the problem of high tumor IFP [89, $113,114]$ and improves treatment effectiveness, thereby reducing incomplete tumor response, rapid disease relapse, and development of drug resistance due to suboptimal doses, which are often seen when using conventional chemotherapies.
The use of peptides as targeting ligands offers several advantages, including ease of synthesis, structural simplicity, low cost, low immunogenicity, small size, ready diffusion, and simple targeted formulation assembly, as compared to larger biomolecules, such as antibodies. Previous studies showed that using larger biomolecules as targeting ligands may increase the clearance of antibody-modified nanoparticles from the blood [115-117]. This may be due to non-specific binding and uptake of nanoparticles by the RES [116]. Earlier studies with other targeted delivery systems have suggested that targeting moieties increase drug accumulation in tumor tissues [118, 119]. However, targeted nanoparticles have not always caused a significant increase in overall tumor accumulation as compared to the non-targeted drugs. The use of macromolecule-targeting ligands, such as antibodies [120] or transferrin [121], has a negligible impact on tumor accumulation and biodistribution. The differential effects of nanoparticles modified with macromolecules and those modified with small molecules may be due to differences in molecular size, affinity, and penetrability of the targeting ligand [122]. It is possible that targeting moieties with high affinity would be subject to greater internalization and degradation by perivascular tumor cells, thereby

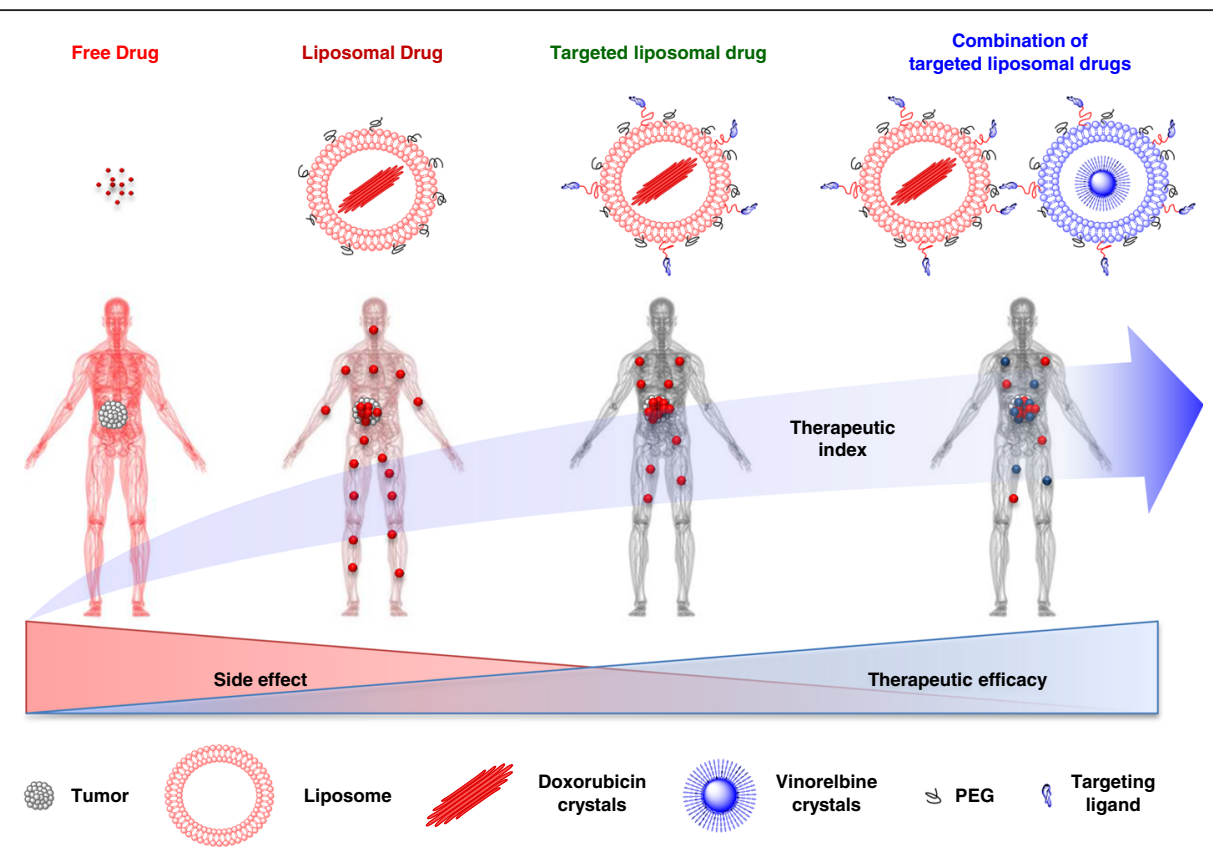

Fig. 5 Combination chemotherapy with ligand-targeted delivery of doxorubicin and vinorelbine. Conventional cancer chemotherapy results in the nonspecific distribution of toxic therapeutic agents in the human body, which induces adverse side effects. To minimize such side effects, attempts have been made to encapsulate the drug in nanoparticles (e.g. liposomes with encapsulated doxorubicin). Although liposomal doxorubicin has fewer adverse effects than those of free drugs, its therapeutic efficacy is insufficient. The specificity of nanoparticles can be further enhanced through modification with targeting ligand. Some cancer cell types develop drug resistance over the course of drug treatment. The use of targeted nanoparticles to deliver multiple chemotherapeutics (with different mechanisms of action) specifically to cancer cells may simultaneously enhance therapeutic efficacy and reduce undesirable side effects 
limiting their penetration of tumors and reducing their tumor retention [123, 124].

Colorectal cancer is one of the most commonly diagnosed cancers and a leading cause of cancer death worldwide. Traditional chemotherapy only has limited therapeutic efficacy due to non-specific delivery to tumor and non-tumor cells, and the development of drug resistance by cancer cells. Therefore, there is an urgent need to develop more tumor-specific targeted drug delivery systems that can more accurately and effectively deliver the anti-cancer chemotherapeutic drugs to the tumor sites. In a recent study, Wu et al. used phage display technology to identify three peptides that could bind to colorectal cancer cells with high specificity and binding affinity [89]. The authors successfully developed a targeted drug by conjugating these peptides to liposomes. This novel targeted liposomal drug combination specifically delivers chemotherapeutics to tumors, resulting in a much higher dose of drugs being accumulated at the tumor site. This significantly increased the tumor inhibition abilities of these two types of chemotherapeutic drugs, and effectively eliminated cancer without inducing any side effects for 150 days, with no trace of recurrence [89]. Thus, this study demonstrated that drugs can be accurately delivered to tumor sites by combining the liposomal drugs with peptides generated using phage display technology, resulting in a nextgeneration targeted anti-cancer drug delivery system.

Advances in nanotechnology have facilitated a multidisciplinary approach toward the development of an ideal "smart nanodrug delivery system," which can be decorated with a targeting ligand for diagnostic or imaging uses, in addition to therapeutic agents of interest (Fig. 5). The availability of such "smart nanodrug delivery systems" in the near future will allow us to detect, diagnose, target, modulate delivery of, and track the progression of therapy both remotely and noninvasively.

\section{Discussion}

Combinatorial phage-displayed random peptide libraries are very valuable tools for studying the interaction between peptides and other substances (or materials). In the past, scientists have been focused on identifying $\mathrm{B} / \mathrm{T}$ cell epitopes [11-19], disease-specific antigen mimics [22-34], receptor agonists/antagonists [35-45], enzyme inhibitors [48-54] and protein partners [55-62]. In recent years, there is an increasing number of researchers who apply this technique to new areas of studies, such as chemistry [70-72] and materials [74-84] science. Although phage display is a powerful technique, it still has some disadvantages. Choosing suitable phage display libraries (i. e. the number of phage-displayed amino acid residues), using applicable selection condition, ensuring the stability and the quality of phage display libraries and following the appropriate screening protocols are all important factors that could impact the quality and desirability of the ligand peptides generated. If these key parameters can be established, functional target peptides are more likely to be obtained. Furthermore, combination of peptide information from phage display with bioinformatics resources may improve the quality of peptides. Tian et al. [125] and Sandman et al. [126] incorporated genetically-encoded non-natural amino acids into phage-displayed libraries and paved the way for wider chemical diversities. Woiwode et al. [127] also combined a new phage-displayed hybrid system with synthetic chemistry through one-compound-one-clone principle (each compound was encoded by a unique nucleotide sequence inserted in a non-coding region of the phage genome). These new techniques help to further advance the possible applications and potentials of phage display going forward.

Cancer cells, different from normal cells, are often found to overexpress certain antigens. Molecules which can recognize these tumor antigens with high specificity are suitable candidates as potential agents for guiding cancer chemotherapy to target tumor sites. The therapeutic monoclonal antibody, antibody-drug conjugates (ADCs), peptide-drug conjugates (PDCs) and peptidemediated drug delivery systems have a major impact on the field of cancer therapy. Therapeutic monoclonal antibody based therapies have achieved remarkable clinical success and become one of the most important strategies for treating patients with hematological malignancies and solid tumors. The direct action of antibodies by receptor blockade or agonist activity may have limited therapeutic activity. Antibody-dependent cellular cytotoxicity (ADCC) and complement-dependent cytotoxicity (CDC) have been demonstrated to have a major role in antibody efficacy [128, 129]. Unfortunately, antibody treatment of patients with malignant tumors may not achieve therapeutic effect due to immune suppression, immune escape, complement inhibition etc. ADCs offer the possibility to overcome this issue by enhancing cytotoxicity to cancer cells, thereby reducing undesired side effects. Although ADCs have already been approved as anticancer therapy, there remain several limitations to this type of therapeutics, such as tumor penetration, high manufacturing costs, and challenging conjugation chemistry [130].

PDCs have similar promise as ADCs but they differ in their pharmacological outcomes. Compared to ADCs, PDCs have additional advantages of having smaller molecular mass, higher tissue penetration, enhanced flexibility and well-defined conjugation chemistry, and faster and easier synthesis process when prepared in a homogenous form [130]. Several peptides included RGD motif peptides [131-136], cell penetrating peptides [137-141], and tumor 
cell specific peptides [142-145] are used for synthesizing PDCs for cancer therapy. After more than decades of research, lots of PDCs have been discovered, and some have been clinically evaluated, although none has yet received regulatory approval. One of the PDCs that has been clinically evaluated and carry most promising is GRN1005. GRN1005 is a LRP-1-targeted peptide-drug conjugate that covalently links paclitaxel to the proprietary 19 amino acid peptide angiopep-2, in a 3:1 ratio. The results from the phase I trial of GRN1005 showed the drug candidate to have acceptable safety profile. GRN1005 is currently undergoing Phase II trials to demonstrate the efficacy, safety, and tolerability of GRN1005 in patients with brain metastases from non-small cell lung cancer (NCT01497665). In addition, GRN1005 in combination with Trastuzumab (Herceptin ${ }^{\circ}$ ) has advanced to Phase II studies as a therapeutic agent for HER2 positive metastatic breast cancer (NCT01480583) [146]. However, one major drawback of PDCs that limits their clinical uses is their stability. PDCs are highly proteolytic unstable, which results in their short half-life in circulation and poor pharmacokinetics. In addition, the relative small molecular weight of PDCs would be rapidly eliminated through renal excretory system.

Neither ADCs nor PDCs allows for high drug payloads on the conjugates molecule. The major challenges facing most ADCs and PDCs are their relatively low capacity for drugs. Hence, more effective payload strategies using different carriers are urgently needed. In addition to ADCs and PDCs, nanoparticles modified with targeting ligand are more effective payload strategies. Nanoparticles as potential vehicle for encapsulating chemotherapeutics can achieve higher drug-loading efficiency. Nanoparticles have been shown to increase the drugloading capacity by approximately a thousand-fold compared to ADCs and PDCs [89]. Much enhanced drug loading capacity and higher tumor cell specificity render nanoparticles as potentially more promising targeted drugs as a result of their higher efficacy and lower toxicity [89]. ADCs, PDCs and peptide-mediated drug delivery systems have shown considerable promise in improving the delivery of drug to tumor and limiting off-target toxicities simultaneously. These targeting therapeutics represent promising new frontier in cancer treatment.

Despite having the advantages of increased therapeutic efficacy, many challenges still remain for nanoparticles, including potential for off-target effects, ligand stability, immune responses triggering and drugs delivery efficiency in the cytoplasm of target cells. In particular, the rapid clearance of these nanodrugs by the cells of the reticuloendothelial system (RES)/mononuclear phagocyte system (MPS), especially liver and spleen, can lead to increased toxicity to the off-target organs and reduced therapeutic efficacy. However, a recent publication suggested that such off-target effects can be reduced by Intralipid $20 \%$ (a FDA-approved fat emulsion used as parenteral nutrition source), which could decrease the toxicities in liver and spleen and increase the bioavailability of dichloro ( 1,2 -diaminocyclohexane) platinum (II)-loaded and hyaluronic acid polymer-coated nanoparticle (DACHPt/HANP) by possibly inhibiting peritoneal clearance and impairing the phagocytic activity of Kupffer cells [147]. Whether such reduced off target effects can also be observed in liposomal based drug delivery system is worthwhile further investigating.

Drug delivery using antibodies or ligands that bind to specific receptor molecules on tumor target cells allow increased drug accumulation at the target tumor site, however, the actual percentage of drug accumulated at the tumor site was often only a few percent of the total dose administered. Identification of effective ligand-receptor interaction may help to improve the effectiveness of active targeting. In the field of targeted drug delivery, scientists still have a long way to go, but this may change within the next couple of years. Over time, the number of targeted drug-delivery nanoparticles approved by the FDA is expected to increase.

\section{Conclusions}

Although cancer drugs continue to be discovered, most of these drugs have only limited efficacy against cancer, with less than ideal ability to prolong the lives of cancer patients. Small molecule drugs have the advantage of having higher tissue penetration abilities, but they are non-specific to tumors and have a relatively short halflife. Protein drugs are highly tumor-specific; however, they have lower tumor penetration abilities due to their larger molecular sizes. Peptide-mediated drug delivery systems combine the potent small molecule drugs with high specificity of peptides, thus leveraging the benefits of the two therapeutic regimens while reducing their disadvantages. An ideal drug delivery system should achieve a high level of clinical efficacy and minimize the adverse effects. The development of targeting liposomes can improve drug delivery to the target tissue and reduce drug distribution to nontarget tissues, resulting in increased therapeutic activity with minimal side effects. Peptidemediated liposomes that target tumor cells and vasculature represent a new generation of chemotherapeutic delivery systems. They offer superior pharmacokinetics, controlled biodistribution, greater efficacy, and enhanced safety profiles, and simultaneously improve eradication of disease and reduce common side effects. This has been a long sought-after goal in the development of chemotherapeutic drugs. The modular organization of targeting liposome technology makes it possible to combine peptides with a series of liposomal drugs to 
yield next-generation targeted agents, such as peptidemediated targeting liposomes. However, to date, no peptide-drug conjugates or peptide-modified nanoparticles have successfully reached the market. However, certain hurdles must be overcome before peptides can be widely used as targeting moieties, including development of the appropriate ligand for the targeted receptor, understanding the mechanisms of ligand-receptor uptake, disposition, trafficking, and recycling, and compliance with Chemistry, Manufacturing, and Control (CMC) requirements.

\begin{abstract}
Abbreviations
ADCC: antibody-dependent cellular cytotoxicity; ADCs: antibody-drug conjugates; AEG-1: astrocyte elevated gene-1; AIV: avian influenza viruses; CDC: complement-dependent cytotoxicity; CMC: chemistry, manufacturing, and control; CMV: cytomegalovirus; DHF: hemorrhagic fever; DSS: dengue shock syndrome; DTSSP: 3,3'-dithiobis[sulfosuccinimidyl propionate]; EpoR: erythropoietin receptor; hCXCL8: human CXC ligand 8; hnRNP: heterogenous ribonucleoproteins; HPV: human papillomavirus; IFP: interstitial fluid pressure; mAbs: monoclonal antibodies; MMPs: matrix metalloproteinases; MPS: mononuclear phagocyte system; PAK: p21-activated kinase; PDCs: peptide-drug conjugates; RES: reticuloendothelial system; SARS: severe acute respiratory syndrome; SH: Src homology; TIMP2: metalloproteinases-2; TpoR: thrombopoietin receptor; VEGF: vascular endothelial growth factor.
\end{abstract}

\section{Competing interests}

The authors declare that they have no competing interests.

\section{Authors' contributions}

$\mathrm{H}-\mathrm{CW}, \mathrm{C}-\mathrm{HW}, \mathrm{I-JL}$, and R-ML contributed to the literature review, writing, and figure design. $\mathrm{H}-\mathrm{CW}$ and $\mathrm{C}-\mathrm{HW}$ compiled the manuscript and revised it critically to meet publication standards. All authors read and approved the final manuscript.

\section{Acknowledgements}

Our laboratory is supported by grants from Academia Sinica and the Ministry of Science and Technology, Taiwan (to H-C Wu).

\section{Received: 29 August 2015 Accepted: 11 January 2016}

Published online: 19 January 2016

\section{References}

1. Smith GP. Filamentous fusion phage: novel expression vectors that display cloned antigens on the virion surface. Science. 1985;228(4705):1315-7.

2. Huang J, Honda W. CED: a conformational epitope database. BMC Immunol. 2006;7:7.

3. Geysen HM, Meloen RH, Barteling SJ. Use of peptide synthesis to probe viral antigens for epitopes to a resolution of a single amino acid. Proc Natl Acad Sci U S A. 1984:81(13):3998-4002.

4. Lo Conte L, Chothia C, Janin J. The atomic structure of protein-protein recognition sites. J Mol Biol. 1999;285(5):2177-98,

5. Dummer R, Mittelman A, Fanizzi FP, Lucchese G, Willers J, Kanduc D. Nonself-discrimination as a driving concept in the identification of an immunodominant HMW-MAA epitopic peptide sequence by autoantibodies from melanoma cancer patients. Int J Cancer. 2004;111(5):720-6.

6. Kuntz ID, Blaney JM, Oatley SJ, Langridge R, Ferrin TE. A geometric approach to macromolecule-ligand interactions. J Mol Biol. 1982;161(2):269-88.

7. Benjamin DC, Perdue SS. Site-Directed Mutagenesis in Epitope Mapping. Methods. 1996;9(3):508-15.

8. Enshell-Seijfers D, Denisov D, Groisman B, Smelyanski L, Meyuhas R, Gross G, et al. The mapping and reconstitution of a conformational discontinuous B-cell epitope of HIV-1. J Mol Biol. 2003;334(1):87-101.

9. Oleksiewicz MB, Botner A, Toft P, Normann P, Storgaard T. Epitope mapping porcine reproductive and respiratory syndrome virus by phage display: the nsp2 fragment of the replicase polyprotein contains a cluster of B-cell epitopes. J Virol. 2001;75(7):3277-90.

10. Riemer AB, Kraml G, Scheiner O, Zielinski CC, Jensen-Jarolim E. Matching of trastuzumab (Herceptin) epitope mimics onto the surface of Her-2/neu-a new method of epitope definition. Mol Immunol. 2005;42(9):1121-4.

11. Chen YC, Huang HN, Lin CT, Chen YF, King CC, Wu HC. Generation and characterization of monoclonal antibodies against dengue virus type 1 for epitope mapping and serological detection by epitope-based peptide antigens. Clin Vaccine Immunol. 2007;14(4):404-11.

12. Wang X, Zhao Q, Dang L, Sun Y, Gao J, Liu B, et al. Characterization of Two Novel Linear B-Cell Epitopes in the Capsid Protein of Avian Hepatitis E Virus (HEV) That Are Common to Avian, Swine, and Human HEVs. J Virol. 2015; 89(10):5491-501.

13. Wu HC, Huang YL, Chao TT, Jan JT, Huang JL, Chiang HY, et al. Identification of B-cell epitope of dengue virus type 1 and its application in diagnosis of patients. J Clin Microbiol. 2001;39(3):977-82.

14. Wu HC, Yeh $C T$, Huang YL, Tarn LJ, Lung CC. Characterization of neutralizing antibodies and identification of neutralizing epitope mimics on the Clostridium botulinum neurotoxin type A. Appl Environ Microbiol. 2001; 67(7):3201-7.

15. Wu HC, Jung MY, Chiu CY, Chao TT, Lai SC, Jan JT, et al. Identification of a dengue virus type 2 (DEN-2) serotype-specific B-cell epitope and detection of DEN-2-immunized animal serum samples using an epitope-based peptide antigen. J Gen Virol. 2003;84(Pt 10):2771-9.

16. Li PC, Liao MY, Cheng PC, Liang JJ, Liu IJ, Chiu CY, et al. Development of a humanized antibody with high therapeutic potential against dengue virus type 2. PLoS Negl Trop Dis. 2012;6(5), e1636.

17. Liu IJ, Hsueh PR, Lin CT, Chiu CY, Kao CL, Liao MY, et al. Disease-specific B Cell epitopes for serum antibodies from patients with severe acute respiratory syndrome (SARS) and serologic detection of SARS antibodies by epitope-based peptide antigens. J Infect Dis. 2004;190(4):797-809.

18. Santamaria H, Manoutcharian K, Rocha L, Gonzalez E, Acero G, Govezensky T, et al. Identification of peptide sequences specific for serum antibodies from human papillomavirus-infected patients using phage display libraries. Clin Immunol. 2001;101(3):296-302.

19. Khurana S, Suguitan Jr AL, Rivera Y, Simmons CP, Lanzavecchia A, Sallusto F, et al. Antigenic fingerprinting of $\mathrm{H} 5 \mathrm{~N} 1$ avian influenza using convalescent sera and monoclonal antibodies reveals potential vaccine and diagnostic targets. PLoS Med. 2009;6(4), e1000049.

20. Zhou Z, Gao X, Wang Y, Zhou H, Wu C, Paranhos-Baccala G, et al. Conserved B-cell epitopes among human bocavirus species indicate potential diagnostic targets. PLoS One. 2014;9(1):e86960.

21. Malito E, Faleri A, Lo Surdo P, Veggi D, Maruggi G, Grassi E, et al. Defining a protective epitope on factor $\mathrm{H}$ binding protein, a key meningococcal virulence factor and vaccine antigen. Proc Natl Acad Sci U S A. 2013;110(9):3304-9.

22. Folgori A, Tafi R, Meola A, Felici F, Galfre G, Cortese R, et al. A general strategy to identify mimotopes of pathological antigens using only random peptide libraries and human sera. EMBO J. 1994;13(9):2236-43.

23. Prezzi C, Nuzzo M, Meola A, Delmastro P, Galfre G, Cortese R, et al. Selection of antigenic and immunogenic mimics of hepatitis $C$ virus using sera from patients. J Immunol. 1996;156(11):4504-13.

24. Dybwad A, Forre O, Kjeldsen-Kragh J, Natvig JB, Sioud M. Identification of new $B$ cell epitopes in the sera of rheumatoid arthritis patients using a random nanopeptide phage library. Eur J Immunol. 1993:23(12):3189-93.

25. Cortese I, Tafi R, Grimaldi LM, Martino G, Nicosia A, Cortese R. Identification of peptides specific for cerebrospinal fluid antibodies in multiple sclerosis by using phage libraries. Proc Natl Acad Sci U S A. 1996;93(20):11063-7.

26. Bowditch RD, Tani P, Fong KC, McMillan R. Characterization of autoantigenic epitopes on platelet glycoprotein IIb/llla using random peptide libraries. Blood. 1996;88(12):4579-84.

27. Gevorkian G, Manoutcharian K, Almagro JC, Govezensky T, Dominguez $V$. Identification of autoimmune thrombocytopenic purpura-related epitopes using phage-display peptide library. Clin Immunol Immunopathol. 1998;86(3):305-9.

28. Manoutcharian K, Sotelo J, Garcia E, Cano A, Gevorkian G. Characterization of cerebrospinal fluid antibody specificities in neurocysticercosis using phage display peptide library. Clin Immunol. 1999;91(1):117-21.

29. Chen Y, Luo W, Song H, Yin B, Tang J, Chen Y, et al. Mimotope ELISA for detection of broad spectrum antibody against avian $\mathrm{H} 5 \mathrm{~N} 1$ influenza virus. PLoS One. 2011;6(9), e24144. 
30. Araujo GR, Vaz ER, Fujimura PT, Fonseca JE, de Lima LM, Canhao H, et al Improved serological detection of rheumatoid arthritis: a highly antigenic mimotope of carbonic anhydrase III selected in a murine model by phage display. Arthritis Res Ther. 2015;17:168.

31. Yu RK, Usuki S, Itokazu Y, Wu HC. Novel GM1 ganglioside-like peptide mimics prevent the association of cholera toxin to human intestinal epithelial cells in vitro. Glycobiology. 2015.

32. Lunardi C, Bason C, Navone R, Millo E, Damonte G, Corrocher R, et al. Systemic sclerosis immunoglobulin $\mathrm{G}$ autoantibodies bind the human cytomegalovirus late protein UL94 and induce apoptosis in human endothelial cells. Nat Med. 2000;6(10):1183-6.

33. Liu IJ, Chiu CY, Chen YC, Wu HC. Molecular mimicry of human endothelial cell antigen by autoantibodies to nonstructural protein 1 of dengue virus. J Biol Chem. 2011;286(11):9726-36.

34. Mintz PJ, Rietz AC, Cardo-Vila M, Ozawa MG, Dondossola E, Do KA, et al. Discovery and horizontal follow-up of an autoantibody signature in human prostate cancer. Proc Natl Acad Sci U S A. 2015;112(8):2515-20.

35. Arinaminpathy $Y$, Khurana E, Engelman DM, Gerstein MB. Computational analysis of membrane proteins: the largest class of drug targets. Drug Discov Today. 2009:14(23-24):1130-5.

36. Deller MC, Yvonne JE. Cell surface receptors. Curr Opin Struct Biol. 2000;10(2):213-9.

37. Wrighton NC, Farrell FX, Chang R, Kashyap AK, Barbone FP, Mulcahy LS, et al. Small peptides as potent mimetics of the protein hormone erythropoietin. Science. 1996;273(5274):458-64.

38. Cwirla SE, Balasubramanian P, Duffin DJ, Wagstrom CR, Gates CM, Singer SC, et al. Peptide agonist of the thrombopoietin receptor as potent as the natural cytokine. Science. 1997;276(5319):1696-9

39. Su JL, Lai KP, Chen CA, Yang CY, Chen PS, Chang CC, et al. A novel peptide specifically binding to interleukin-6 receptor (gp80) inhibits angiogenesis and tumor growth. Cancer Res. 2005;65(11):4827-35.

40. Hetian L, Ping A, Shumei S, Xiaoying L, Luowen $H$, Jian W, et al. A novel peptide isolated from a phage display library inhibits tumor growth and metastasis by blocking the binding of vascular endothelial growth factor to its kinase domain receptor. J Biol Chem. 2002;277(45):43137-42.

41. Yanofsky SD, Baldwin DN, Butler JH, Holden FR, Jacobs JW, Balasubramanian P, et al. High affinity type I interleukin 1 receptor antagonists discovered by screening recombinant peptide libraries. Proc Natl Acad Sci U S A. 1996;93(14):7381-6.

42. Heller T, Hennecke M, Baumann U, Gessner JE. zu Vilsendorf AM, Baensch M et al. Selection of a $\mathrm{C} 5$ a receptor antagonist from phage libraries attenuating the inflammatory response in immune complex disease and ischemia/reperfusion injury. J Immunol. 1999:163(2):985-94.

43. Binetruy-Tournaire R, Demangel C, Malavaud B, Vassy R, Rouyre S, Kraemer $M$, et al. Identification of a peptide blocking vascular endothelial growth factor (VEGF)-mediated angiogenesis. EMBO J. 2000;19(7):1525-33.

44. An P, Lei H, Zhang J, Song S, He L, Jin G, et al. Suppression of tumor growth and metastasis by a VEGFR-1 antagonizing peptide identified from a phage display library. Int J Cancer. 2004;111(2):165-73.

45. Houimel M, Mazzucchelli L. hCXCR1 and hCXCR2 antagonists derived from combinatorial peptide libraries. Cytokine. 2012;57(3):322-31.

46. Hessling J, Lohse MJ, Klotz KN. Peptide G protein agonists from a phage display library. Biochem Pharmacol. 2003;65(6):961-7.

47. Malik S, Ghosh M, Bonacci TM, Tall GG, Smrcka AV. Ric-8 enhances G protein betagamma-dependent signaling in response to betagamma-binding peptides in intact cells. Mol Pharmacol. 2005;68(1):129-36.

48. Diamond SL. Methods for mapping protease specificity. Curr Opin Chem Biol. 2007;11(1):46-51.

49. Kehoe JW, Kay BK. Filamentous phage display in the new millennium. Chem Rev. 2005;105(11):4056-72.

50. Zani ML, Moreau T. Phage display as a powerful tool to engineer protease inhibitors. Biochimie. 2010;92(11):1689-704.

51. Bahudhanapati H, Zhang Y, Sidhu SS, Brew K. Phage display of tissue inhibitor of metalloproteinases-2 (TIMP-2): identification of selective inhibitors of collagenase-1 (metalloproteinase 1 (MMP-1)). J Biol Chem. 2011:286(36):31761-70.

52. Lin SH, Chang DK, Chou MJ, Huang KJ, Shiuan D. Peptide inhibitors of human HMG-CoA reductase as potential hypocholesterolemia agents. Biochem Biophys Res Commun. 2015;456(1):104-9.
53. Mund T, Lewis MJ, Maslen S, Pelham HR. Peptide and small molecule inhibitors of HECT-type ubiquitin ligases. Proc Natl Acad Sci U S A. 2014; 111(47):16736-41

54. Lee YC, Hsiao NW, Tseng TS, Chen WC, Lin HH, Leu SJ, et al. Phage displaymediated discovery of novel tyrosinase-targeting tetrapeptide inhibitors reveals the significance of $\mathrm{N}$-terminal preference of cysteine residues and their functional sulfur atom. Mol Pharmacol. 2015;87(2):218-30.

55. Hertveldt K, Belien T, Volckaert G. General M13 phage display: M13 phage display in identification and characterization of protein-protein interactions. Methods Mol Biol. 2009;502:321-39.

56. Fuh G, Pisabarro MT, Li Y, Quan C, Lasky LA, Sidhu SS. Analysis of PDZ domain-ligand interactions using carboxyl-terminal phage display. J Biol Chem. 2000;275(28):21486-91.

57. James KJ, Hancock MA, Gagnon JN, Coulton JW. TonB interacts with BtuF, the Escherichia coli periplasmic binding protein for cyanocobalamin. Biochemistry. 2009;48(39):9212-20.

58. Caberoy NB, Zhou Y, Jiang X, Alvarado G, Li W. Efficient identification of tubby-binding proteins by an improved system of T7 phage display. J Mol Recognit. 2010;23(1):74-83.

59. Karkkainen S, Hiipakka M, Wang JH, Kleino I, Vaha-Jaakkola M, Renkema GH, et al. Identification of preferred protein interactions by phage-display of the human Src homology-3 proteome. EMBO Rep. 2006;7(2):186-91.

60. Voss $\mathrm{M}$, Lettau $\mathrm{M}$, Janssen $\mathrm{O}$. Identification of $\mathrm{SH} 3$ domain interaction partners of human FasL (CD178) by phage display screening. BMC Immunol. 2009;10:53.

61. Kofler M, Motzny K, Beyermann M, Freund C. Novel interaction partners of the CD2BP2-GYF domain. J Biol Chem. 2005;280(39):33397-402.

62. Abu-Odeh M, Bar-Mag T, Huang H, Kim T, Salah Z, Abdeen SK, et al. Characterizing WW domain interactions of tumor suppressor WWOX reveals its association with multiprotein networks. J Biol Chem. 2014;289(13):8865-80.

63. Forster-Waldl E, Riemer AB, Dehof AK, Neumann D, Bramswig K, BoltzNitulescu G, et al. Isolation and structural analysis of peptide mimotopes for the disialoganglioside GD2, a neuroblastoma tumor antigen. Mol Immunol. 2005:42(3):319-25.

64. Peng Y, Zhang Y, Mitchell WJ, Zhang G. Development of a lipopolysaccharide-targeted peptide mimic vaccine against Q fever. J Immunol. 2012;189(10):4909-20.

65. Naz RK. Status of contraceptive vaccines. Am J Reprod Immunol. 2009;61(1): $11-8$.

66. Knittelfelder R, Riemer AB, Jensen-Jarolim E. Mimotope vaccination-from allergy to cancer. Expert Opin Biol Ther. 2009;9(4):493-506.

67. Lamichhane TN, Abeydeera ND, Duc AC, Cunningham PR, Chow CS. Selection of peptides targeting helix 31 of bacterial 165 ribosomal RNA by screening M13 phage-display libraries. Molecules. 2011;16(2):1211-39.

68. Li M, DuC AC, Klosi E, Pattabiraman S, Spaller MR, Chow CS. Selection of peptides that target the aminoacyl-tRNA site of bacterial 165 ribosomal RNA. Biochemistry. 2009;48(35):8299-311.

69. Bose D, Nahar S, Rai MK, Ray A, Chakraborty K, Maiti S. Selective inhibition of miR-21 by phage display screened peptide. Nucleic Acids Res. 2015;43(8):4342-52

70. Rozinov MN, Nolan GP. Evolution of peptides that modulate the spectral qualities of bound, small-molecule fluorophores. Chem Biol. 1998:5(12):713-28

71. Zhao SW, Shen PP, Zhou Y, Wei Y, Xin XB, Hua ZC. Selecting peptide ligands of microcystin-LR from phage displayed random libraries. Environ Int. 2005; 31(4):535-41.

72. Aoki S, Morohashi K, Sunoki T, Kuramochi K, Kobayashi S, Sugawara F. Screening of paclitaxel-binding molecules from a library of random peptides displayed on T7 phage particles using paclitaxel-photoimmobilized resin. Bioconjug Chem. 2007;18(6):1981-6.

73. Liu Z, Liu J, Wang K, Li W, Shelver WL, Li QX, et al. Selection of phagedisplayed peptides for the detection of imidacloprid in water and soil. Anal Biochem. 2015;485:28-33.

74. Seker UOS, Demir HV. Material Binding Peptides for Nanotechnology. Molecules. 2011;16(2):1426

75. Whaley SR, English DS, Hu EL, Barbara PF, Belcher AM. Selection of peptides with semiconductor binding specificity for directed nanocrystal assembly. Nature. 2000:405(6787):665-8.

76. Mao C, Flynn CE, Hayhurst A, Sweeney R, Qi J, Georgiou G, et al. Viral assembly of oriented quantum dot nanowires. Proc Natl Acad Sci U S A 2003;100(12):6946-51. 
77. Naik RR, Brott LL, Clarson SJ, Stone MO. Silica-precipitating peptides isolated from a combinatorial phage display peptide library. J Nanosci Nanotechnol. 2002;2(1):95-100.

78. Brown S. Engineered iron oxide-adhesion mutants of the Escherichia coli phage lambda receptor. Proc Natl Acad Sci U S A. 1992;89(18):8651-5.

79. Chen H, Su X, Neoh KG, Choe WS. QCM-D analysis of binding mechanism of phage particles displaying a constrained heptapeptide with specific affinity to SiO2 and TiO2. Anal Chem. 2006;78(14):4872-9.

80. Sanghvi AB, Miller KPH, Belcher AM, Schmidt CE. Biomaterials functionalization using a novel peptide that selectively binds to a conducting polymer. Nat Mater. 2005;4(6):496-502.

81. Naik RR, Stringer SJ, Agarwal G, Jones SE, Stone MO. Biomimetic synthesis and patterning of silver nanoparticles. Nat Mater. 2002;1(3):169-72.

82. Brown S. Metal-recognition by repeating polypeptides. Nat Biotechnol. 1997;15(3):269-72.

83. Sano K, Sasaki H, Shiba K. Specificity and biomineralization activities of Tibinding peptide-1 (TBP-1). Langmuir. 2005;21(7):3090-5.

84. Sarikaya M, Tamerler C, Jen AK, Schulten K, Baneyx F. Molecular biomimetics: nanotechnology through biology. Nat Mater. 2003;2(9):577-85.

85. Barry MA, Dower WJ, Johnston SA. Toward cell-targeting gene therapy vectors: selection of cell-binding peptides from random peptide-presenting phage libraries. Nat Med. 1996;2(3):299-305.

86. Lo A, Lin CT, Wu HC. Hepatocellular carcinoma cell-specific peptide ligand for targeted drug delivery. Mol Cancer Ther. 2008;7(3):579-89.

87. Lee TY, Wu HC, Tseng YL, Lin CT. A novel peptide specifically binding to nasopharyngeal carcinoma for targeted drug delivery. Cancer Res. 2004; 64(21):8002-8.

88. Chang DK, Lin CT, Wu CH, Wu HC. A novel peptide enhances therapeutic efficacy of liposomal anti-cancer drugs in mice models of human lung cancer. PLoS One. 2009:4(1):e4171.

89. Wu CH, Kuo YH, Hong RL, Wu HC. alpha-Enolase-binding peptide enhances drug delivery efficiency and therapeutic efficacy against colorectal cancer. Sci Transl Med. 2015;7(290):290ra91.

90. Lu RM, Chen MS, Chang DK, Chiu CY, Lin WC, Yan SL, et al. Targeted drug delivery systems mediated by a novel Peptide in breast cancer therapy and imaging. PLoS One. 2013;8(6), e66128.

91. Gray BP, Brown KC. Combinatorial peptide libraries: mining for cell-binding peptides. Chem Rev. 2014;114(2):1020-81.

92. Lunder M, Bratkovic T, Urleb U, Kreft S, Strukelj B. Ultrasound in phage display: a new approach to nonspecific elution. Biotechniques. 2008; 44(7):893-900

93. Gray BP, Li S, Brown KC. From phage display to nanoparticle delivery: functionalizing liposomes with multivalent peptides improves targeting to a cancer biomarker. Bioconjug Chem. 2013;24(1):85-96.

94. Brown KC. Peptidic tumor targeting agents: the road from phage display peptide selections to clinical applications. Curr Pharm Des. 2010; 16(9):1040-54.

95. Pasqualini R, Ruoslahti E. Organ targeting in vivo using phage display peptide libraries. Nature. 1996:380(6572):364-6.

96. Laakkonen P, Porkka K, Hoffman JA, Ruoslahti E. A tumor-homing peptide with a targeting specificity related to lymphatic vessels. Nat Med. 2002;8(7):751-5.

97. Lee TY, Lin CT, Kuo SY, Chang DK, Wu HC. Peptide-mediated targeting to tumor blood vessels of lung cancer for drug delivery. Cancer Res. 2007; 67(22):10958-65.

98. Molenaar TJ, Michon I, de Haas SA, van Berkel TJ, Kuiper J, Biessen EA. Uptake and processing of modified bacteriophage M13 in mice: implications for phage display. Virology. 2002;293(1):182-91.

99. Zou J, Dickerson MT, Owen NK, Landon LA, Deutscher SL. Biodistribution of filamentous phage peptide libraries in mice. Mol Biol Rep. 2004;31(2):121-9.

100. Rajotte D, Arap W, Hagedorn M, Koivunen E, Pasqualini R, Ruoslahti E. Molecular heterogeneity of the vascular endothelium revealed by in vivo phage display. J Clin Invest. 1998;102(2):430-7.

101. Babickova J, Tothova L, Boor P, Celec P. In vivo phage display-a discovery tool in molecular biomedicine. Biotechnol Adv. 2013;31(8):1247-59.

102. Krumpe LR, Mori T. The Use of Phage-Displayed Peptide Libraries to Develop Tumor-Targeting Drugs. Int J Pept Res Ther. 2006;12(1):79-91.

103. Mori T. Cancer-specific ligands identified from screening of peptide-display libraries. Curr Pharm Des. 2004;10(19):2335-43.
104. Rafii S, Avecilla ST, Jin DK. Tumor vasculature address book: identification of stage-specific tumor vessel zip codes by phage display. Cancer Cell. 2003;4(5):331-3.

105. Chang DK, Chiu CY, Kuo SY, Lin WC, Lo A, Wang YP, et al. Antiangiogenic targeting liposomes increase therapeutic efficacy for solid tumors. J Biol Chem. 2009;284(19):12905-16.

106. Laakkonen P, Zhang L, Ruoslahti E. Peptide targeting of tumor lymph vessels. Ann N Y Acad Sci. 2008;1131:37-43.

107. Arap W, Kolonin MG, Trepel M, Lahdenranta J, Cardo-Vila M, Giordano RJ, et al. Steps toward mapping the human vasculature by phage display. Nat Med. 2002;8(2):121-7.

108. Krag DN, Shukla GS, Shen GP, Pero S, Ashikaga T, Fuller S, et al. Selection of tumor-binding ligands in cancer patients with phage display libraries. Cancer Res. 2006;66(15):7724-33.

109. Allen TM. Ligand-targeted therapeutics in anticancer therapy. Nat Rev Cancer. 2002;2(10):750-63.

110. Bolotin EM, Cohen R, Bar LK, Emanuel N, Ninio S, Barenholz Y, et al. Ammonium Sulfate Gradients for Efficient and Stable Remote Loading of Amphipathic Weak Bases into Liposomes and Ligandoliposomes. J Liposome Res. 1994;4(1):455-79.

111. Boman NL, Bally MB, Cullis PR, Mayer LD, Webb MS. Encapsulation of Vincristine in Liposomes Reduces its Toxicity and Improves its Anti-Tumor Efficacy. J Liposome Res. 1995;5(3):523-41.

112. Jain RK. Transport of molecules in the tumor interstitium: a review. Cancer Res. 1987;47(12):3039-51.

113. Heldin $\mathrm{CH}$, Rubin $\mathrm{K}$, Pietras $\mathrm{K}$, Ostman A. High interstitial fluid pressure - an obstacle in cancer therapy. Nat Rev Cancer. 2004;4(10):806-13.

114. Wu H-C, Chang D-K, Huang C-T. Targeted therapy for cancer. J Cancer Mol. 2006;2(2):57-66

115. Harding JA, Engbers CM, Newman MS, Goldstein NI, Zalipsky S. Immunogenicity and pharmacokinetic attributes of poly(ethylene glycol)-grafted immunoliposomes. Biochim Biophys Acta. 1997;1327(2):181-92.

116. Koning GA, Kamps JA, Scherphof GL. Interference of macrophages with immunotargeting of liposomes. J Liposome Res. 2002:12(1-2):107-19.

117. ElBayoumi TA, Torchilin VP. Tumor-targeted nanomedicines: enhanced antitumor efficacy in vivo of doxorubicin-loaded, long-circulating liposomes modified with cancer-specific monoclonal antibody. Clin Cancer Res. 2009; 15(6):1973-80.

118. Liu Z, Cai W, He L, Nakayama N, Chen K, Sun X, et al. In vivo biodistribution and highly efficient tumour targeting of carbon nanotubes in mice. Nat Nanotechnol. 2007;2(1):47-52.

119. Qian X, Peng XH, Ansari DO, Yin-Goen Q, Chen GZ, Shin DM, et al. In vivo tumor targeting and spectroscopic detection with surface-enhanced Raman nanoparticle tags. Nat Biotechnol. 2008;26(1):83-90.

120. Kirpotin DB, Drummond DC, Shao Y, Shalaby MR, Hong K, Nielsen UB, et al. Antibody targeting of long-circulating lipidic nanoparticles does not increase tumor localization but does increase internalization in animal models. Cancer Res. 2006;66(13):6732-40.

121. Bartlett DW, Su H, Hildebrandt IJ, Weber WA, Davis ME. Impact of tumorspecific targeting on the biodistribution and efficacy of siRNA nanoparticles measured by multimodality in vivo imaging. Proc Natl Acad Sci U S A. 2007; 104(39):15549-54

122. Moghimi SM, Hunter AC, Andresen TL. Factors controlling nanoparticle pharmacokinetics: an integrated analysis and perspective. Annu Rev Pharmacol Toxicol. 2012;52:481-503.

123. Adams GP, Schier R, McCall AM, Simmons HH, Horak EM, Alpaugh RK, et al. High affinity restricts the localization and tumor penetration of single-chain fv antibody molecules. Cancer Res. 2001;61(12):4750-5.

124. Rudnick SI, Lou J, Shaller CC, Tang Y, Klein-Szanto AJ, Weiner LM, et al. Influence of affinity and antigen internalization on the uptake and penetration of Anti-HER2 antibodies in solid tumors. Cancer Res. 2011; 71(6):2250-9.

125. Tian F, Tsao ML, Schultz PG. A phage display system with unnatural amino acids. J Am Chem Soc. 2004;126(49):15962-3.

126. Sandman KE, Benner JS, Noren CJ. Phage Display of Selenopeptides. J Am Chem Soc. 2000;122(5):960-1.

127. Woiwode TF, Haggerty JE, Katz R, Gallop MA, Barrett RW, Dower WJ, et al. Synthetic compound libraries displayed on the surface of encoded bacteriophage. Chem Biol. 2003;10(9):847-58. 
128. Musolino A, Naldi N, Bortesi B, Pezzuolo D, Capelletti M, Missale G, et al. Immunoglobulin $\mathrm{G}$ fragment $\mathrm{C}$ receptor polymorphisms and clinical efficacy of trastuzumab-based therapy in patients with HER-2/neu-positive metastatic breast cancer. J Clin Oncol. 2008:26(11):1789-96.

129. Bibeau F, Lopez-Crapez E, Di Fiore F, Thezenas S, Ychou M, Blanchard F, et al. Impact of Fc\{gamma\}RIla-Fc\{gamma\}RIlla polymorphisms and KRAS mutations on the clinical outcome of patients with metastatic colorectal cancer treated with cetuximab plus irinotecan. J Clin Oncol. 2009;27(7):1122-9.

130. Firer MA, Gellerman G. Targeted drug delivery for cancer therapy: the other side of antibodies. J Hematol Oncol. 2012;5:70

131. Arap W, Pasqualini R, Ruoslahti E. Cancer treatment by targeted drug delivery to tumor vasculature in a mouse model. Science. 1998;279(5349):377-80.

132. Burkhart DJ, Kalet BT, Coleman MP, Post GC, Koch TH. Doxorubicinformaldehyde conjugates targeting alphavbeta3 integrin. Mol Cancer Ther. 2004;3(12):1593-604

133. Li X, Hou J, Wang C, Liu X, He H, Xu P, et al. Synthesis and biological evaluation of RGD-conjugated MEK1/2 kinase inhibitors for integrin-targeted cancer therapy. Molecules. 2013;18(11):13957-78.

134. Cao Q, Li ZB, Chen K, Wu Z, He L, Neamati N, et al. Evaluation of biodistribution and anti-tumor effect of a dimeric RGD peptide-paclitaxel conjugate in mice with breast cancer. Eur J Nucl Med Mol Imaging. 2008; 35(8):1489-98.

135. Chen X, Plasencia C, Hou Y, Neamati N. Synthesis and biological evaluation of dimeric RGD peptide-paclitaxel conjugate as a model for integrintargeted drug delivery. J Med Chem. 2005;48(4):1098-106

136. Kim JW, Lee HS. Tumor targeting by doxorubicin-RGD-4C peptide conjugate in an orthotopic mouse hepatoma model. Int J Mol Med. 2004;14(4):529-35.

137. Lelle M, Frick SU, Steinbrink K, Peneva K. Novel cleavable cell-penetrating peptide-drug conjugates: synthesis and characterization. J Pept Sci. 2014; 20(5):323-33.

138. Rothbard JB, Garlington S, Lin Q, Kirschberg T, Kreider E, McGrane PL, et al. Conjugation of arginine oligomers to cyclosporin A facilitates topical delivery and inhibition of inflammation. Nat Med. 2000;6(11):1253-7.

139. Miyaji Y, Walter S, Chen L, Kurihara A, Ishizuka T, Saito M, et al. Distribution of KAl-9803, a novel delta-protein kinase C inhibitor, after intravenous administration to rats. Drug Metab Dispos. 2011;39(10):1946-53.

140. Shi NQ, Gao W, Xiang B, Qi XR. Enhancing cellular uptake of activable cellpenetrating peptide-doxorubicin conjugate by enzymatic cleavage. Int J Nanomedicine. 2012;7:1613-21.

141. Meyer-Losic F, Nicolazzi C, Quinonero J, Ribes F, Michel M, Dubois V, et al. DTS-108, a novel peptidic prodrug of SN38: in vivo efficacy and toxicokinetic studies. Clin Cancer Res. 2008:14(7):2145-53.

142. Kurzrock R, Gabrail N, Chandhasin C, Moulder S, Smith C, Brenner A, et al. Safety, pharmacokinetics, and activity of GRN1005, a novel conjugate of angiopep-2, a peptide facilitating brain penetration, and paclitaxel, in patients with advanced solid tumors. Mol Cancer Ther. 2012;11(2):308-16.

143. Yang RC, Huang JT, Chen YL, Hung CC, Liao M, Yao WC, et al. Enthalpydriven nuclease-like activity and mechanism of peptide-chlorambucil conjugates. Org Biomol Chem. 2014;12(27):4890-904.

144. Majumdar S, Kobayashi N, Krise JP, Siahaan TJ. Mechanism of internalization of an ICAM-1-derived peptide by human leukemic cell line HL-60: influence of physicochemical properties on targeted drug delivery. Mol Pharm. 2007; 4(5):749-58.

145. Tai W, Shukla RS, Qin B, Li B, Cheng K. Development of a peptide-drug conjugate for prostate cancer therapy. Mol Pharm. 2011;8(3):901-12.

146. Lin N, Schwartzberg L, Kesari S, Yardley D, Verma S, Anders C, et al. Abstract P3-12-04: A phase 2, multi-center, open label study evaluating the efficacy and safety of GRN1005 alone or in combination with trastuzumab in patients with brain metastases from breast cancer. Cancer Res. 2012;72(24 Supplement):3. 12-04.

147. Liu L, Ye Q, Lu M, Lo YC, Hsu YH, Wei MC, et al. A new approach to reduce toxicities and to improve bioavailabilities of platinum-containing anti-cancer nanodrugs. Sci Rep. 2015;5:10881.

\section{Submit your next manuscript to BioMed Central and we will help you at every step:}

- We accept pre-submission inquiries

- Our selector tool helps you to find the most relevant journal

- We provide round the clock customer support

- Convenient online submission

- Thorough peer review

- Inclusion in PubMed and all major indexing services

- Maximum visibility for your research

Submit your manuscript at www.biomedcentral.com/submit
Biomed Central 